\title{
A NOVEL STRAIN OF Aspergillus niger PRODUCING A COCKTAIL OF HYDROLYTIC DEPOLYMERISING ENZYMES FOR THE PRODUCTION OF SECOND GENERATION BIOFUELS
}

\author{
Namita Bansal, ${ }^{\mathrm{a}}$ Rupinder Tewari, ${ }^{\mathrm{a}}$ Jugal Kishore Gupta, ${ }^{\mathrm{b}}$ Raman Soni, ${ }^{\mathrm{c}}$ and \\ Sanjeev Kumar Soni ${ }^{b}$ *
}

\begin{abstract}
The screening and isolation of fungi producing a cocktail of hydrolytic enzymes was studied. Among the various isolates obtained from different soil samples, a strain NS-2 was selected. The phylogenetic analysis of this strain showed highest homology (99\%) with Aspergillus niger. It was capable of producing cellulolytic, hemicellulolytic, amylolytic, and pectinolytic enzymes in appreciable titers on wheat bran based liquid and solid state media. The mixture of enzymes produced by this organism could effectively hydrolyze various domestic waste residues, revealing conversion efficiencies of 89 to $92 \%$ and produced high reducing sugar yields of 0.48 to $0.66 \mathrm{~g} / \mathrm{g}$ of dry residue. This enzyme cocktail could potentially find a significant application in the conversion of agricultural and other waste residues having cellulose, hemicellulose, starch, and pectin as carbohydrates to produce simpler sugars which can be fermented for the production of second generation biofuels.
\end{abstract}

Keywords: Aspergillus niger; Hydrolytic enzymes; Cellulases; Hemicellulases; Xylanase; Mannanase; Amylases; Pectinases; Second generation biofuel; Lignocellulosics

Contact information: a: Department of Biotechnology, Panjab University, Chandigarh 160014 INDIA; b: Department of Microbiology, Panjab University, Chandigarh 160014 INDIA; c: Department of Biotechnology, D.A.V. College, Sector 10, Chandigarh 160011 INDIA; *Corresponding author: sonisk@pu.ac.in

\section{INTRODUCTION}

The ability of some microorganisms to produce a mixture of enzymes can be a resource for greener and cleaner processes to produce simpler sugars (pentoses and hexoses) from agricultural, agro-industrial, and domestic solid wastes rich in starchy, cellulosic, and hemicellulosic biomass. Fermentable sugars thus obtained can easily be fermented into ethanol, which can then be used as a second generation "biofuel". In the last quarter century, focus has been placed on producing fuel ethanol as a substitute or additive to gasoline. The growing interest for ethanol as a fuel depends on a combination of factors such as environmental, social, and energy security issues.

Agricultural, agro-industrial, and domestic wastes, including sugarcane bagasse, orange bagasse, wheat bran, rice bran, corn straw, corncob, seeds, fruit peels, vegetable peels, and effluents from the paper industry have increased as a result of rising population and industrialization (da Silva et al. 2005). The rising level of these residues is becoming a global problem in terms of space for disposal and environmental pollution caused by their disposal by land-filling. These residues also represent an alternative and cheaper source for microbial growth, aiming at the production of single cell protein (SCP) or 
industrial enzymes for conversion of various polysaccharides into simpler sugars. Most of these residues have similar compositions and are comprised of starch, cellulose, hemicellulose, lignin, and pectin, varying in percentage. Hemicellulose and cellulose represent more than 50\% of the dry weight of agricultural residues (Pandey et al. 2000; da Silva et al. 2005) which can be converted into soluble sugars either by acid or enzymatic hydrolysis, so they can be used as a plentiful and cheap source of renewable energy. For many residues, xylan is the main component of the hemicellulose fraction. Hemicelluloses are usually classified according to the sugar residue present and are generally named as D-xylan, D-galactan, D-mannan, L-arabinan, etc. (Bisaria and Ghose 1981). Cellulose is the most abundant biomass component on the earth (Tomme et al. 1995). It is the primary product of photosynthesis in terrestrial environments, and the most abundant renewable bioresource produced in the biosphere (100 billion dry tons/year) (Jarvis 2003; Zhang and Lynd 2004). Complete enzymatic hydrolysis of cellulose requires synergistic action of three types of enzymes, namely endoglucanase or carboxymethycellulase (CMCase), cellobiohydrolase and $\beta$-glucosidases (Bhat 2000), which are produced by several microorganisms, commonly by bacteria and fungi (Bahkali 1996; Mangelli and Forchiass 1999; Shin et al. 2000; Immanuel et al. 2006).

Pectin and other pectic compounds are complex plant polysaccharides and contribute to the structure of plant tissue (Naidu and Panda 1998). Pectic substances are a part of the primary plant cell wall and middle lamella (Dhillon et al. 2004; Naidu and Panda 1998). The main component in pectin is D-galacturonic acid in the form of macromolecules linked with $\alpha-1,4$-glycosidic bindings. Pectic materials can be degraded by pectinolytic enzymes. Pectinolytic enzymes are multiple and have various forms, as pectin is very complex in nature. Mainly plants and microorganisms synthesize these enzymes. The pectic enzymes are divided into two main groups, viz. depolymerizing pectic enzymes and saponifying enzymes or pectic esterases (Naidu and Panda 1998).

Starch is also present in vegetable peelings and brans and requires the synergistic action of $\alpha$-amylase and glucoamylases for its degradation. Amylases are one of the most important industrial enzymes that have a wide variety of applications in food, fermentation, textiles, and paper (Pandey et al. 2000) ranging from conversion of starch to sugar syrups, to the production of cyclodextrins for the pharmaceutical industry. Though the amylases can be obtained from several sources such as plants, animals, and microbes (Kathiresan and Manivannan 2006; Mishra and Behera 2008), the microbial source is preferred because of its plasticity and vast availability.

Among the various bacteria and fungi capable of producing extracellular depolymerising enzymes, the latter have been found to be better in terms of the range of enzyme varieties and their yields (Bakri et al. 2003). Most reported cellulase producers are Trichoderma and Aspergillus species (Bhatt 2000). A. niger is used industrially for the production of pectinolytic and amylolytic enzymes (Naidu and Panda 1998). In the present study we report a novel fungal strain from natural habitat producing a cocktail of various hydrolytic depolymerising enzymes by solid state and surface culture fermentations on a simple wheat bran based media. 


\section{EXPERIMENTAL}

\section{Screening and Isolation of Fungi Producing Hydrolytic Depolymerising Enzymes}

Samples in the form of rotten foods having fungal growth, agricultural residues (leaves and stalks), and soil were collected locally from Chandigarh city. These samples were taken into the laboratory and labeled for further processing in order to isolate fungi capable of producing various depolymerizing enzymes. Samples were inoculated for enrichment of fungal strains capable of producing various hydrolytic industrial enzymes in $100 \mathrm{~mL}$ Erlenmeyer flasks, each containing $20 \mathrm{~mL}$ of yeast nitrogen base (Hi-Media, Mumbai, India), supplemented separately with $0.5 \%(\mathrm{w} / \mathrm{v})$ of different carbon sources including caboxymethylcellulose (CMC), xylan, locust bean gum, pectin, and starch powder. The flasks were incubated on a rotary shaker $(150 \mathrm{rpm})$ at $30^{\circ} \mathrm{C}$ for 4 days, and the flasks showing microbial growth were processed for the screening and isolation of the desired strains by streaking on potato-agar plates containing either $\mathrm{CMC}$, xylan, locust bean gum, soluble starch, or pectin, and incubating at $30^{\circ} \mathrm{C}$ for 4 days. The potato based medium was prepared by taking $200 \mathrm{~g}$ peeled potato pieces, boiling them in distilled water, extracting the soluble extract by pressing through a muslin cloth, making the total volume to $1000 \mathrm{~mL}$ at $\mathrm{pH} 5.0$, and supplementing separately with $1 \%$ (w/v) of various polysaccharides and 3\% agar for screening of the hydrolytic organisms.

To visualize the hydrolysis zone in CMC- and xylan-supplemented media, the plates were flooded with an aqueous solution of $0.1 \%$ Congo red for $15 \mathrm{~min}$ and washed with $1 \mathrm{M} \mathrm{NaCl}$ (Teather and Wood 1982; Apun et al. 2000). To indicate the cellulase and xylanase activities of the organisms, diameters of clear zone around colonies were measured in CMC- and xylan-containing plates, respectively. The mannanase activity was evaluated by a clear zone around the colonies in locust bean gum plates (Phothichitto et al. 2006). The degradation of starch was evaluated in the starch plates flooded with $0.2 \%$ iodine solution, where the cleared zones were seen around amylase producing colonies under a blue background (Bahadure et al. 2010). The clearing zones around the colonies in pectin containing medium after addition of Logule's iodine solution were investigated and taken as criteria for determining the pectinolytic productivity (Reda et al. 2008). The degradation capabilities of various polysaccharides on agar plates were recorded as clear zone ratios (clear zone diameters/colony diameters).

\section{Morphological Examination of Strain NS-2}

Strain NS-2 was cultivated on a plate of potato dextrose agar (PDA) by incubating at $30^{\circ} \mathrm{C}$ in the dark for 1 week. The spore-producing filamentous fungus was identified to the genus level based on macroscopic and microscopic characteristics (Raper and Fennell 1965; Qi and Kong 1997; Klich 2002). Colony morphology of the fungus NS-2 was examined with both a light microscope and a scanning electron microscope. The goldcoated stubs were examined at different magnifications under a scanning electron microscope, model JSM $6100 \mathrm{SM}$ JEOL at $10 \mathrm{KV}$. Growth response of strain NS-2 after 7 -day incubation at $15,20,25,30,35$, and $40{ }^{\circ} \mathrm{C}$ on malt extract agar (MEA) media in plastic petri dishes were also analyzed. 


\section{Molecular Analysis and Identification of Selected Strain NS-2}

Culture and collection of the mycelium was carried out as reported by Zhao et al. (2004). For sequence analysis, DNA was extracted from the strain NS-2 using a fungal genomic DNA isolation kit (RKT13; Chromous Biotech, India). The 18S rDNA sequences were amplified by PCR with primer pairs ITS1 (5'TCC GTA GGT GAA CCT TGC GG 3') and ITS4 (5'TCC TCC GCT TAT TGA TAT GC 3'). PCR reactions were carried out in one cycle of heat treatment at $94^{\circ} \mathrm{C}$ for $5 \mathrm{~min}$, a total of 35 cycles of denaturing at $94^{\circ} \mathrm{C}$ for $30 \mathrm{sec}$; annealing at $55^{\circ} \mathrm{C}$ for $30 \mathrm{sec}$ and extension at $72^{\circ} \mathrm{C}$ for 15 min; and final extension at $72^{\circ}$ for $15 \mathrm{~min}$. The $100-\mu \mathrm{l}$ PCR reaction mixture contained $400 \mathrm{ng}$ of each primer, $2.5 \mathrm{mM}$ of each dNTPs, $1.5 \mathrm{mM} \mathrm{MgCl}_{2}, 100 \mathrm{ng}$ of template DNA, $3 \mathrm{U}$ of the Taq Polymerase, and $1 \mathrm{x}$ buffer. The PCR products were stored at $4{ }^{\circ} \mathrm{C}$, later analysed by $0.8 \%$ agarose gel electrophoresis, and then sequenced bi-directionally using the forward, reverse primers using ABI 3130 Genetic Analyzer by the service of Chromous Biotech, India. The sequence obtained was submitted to GenBank for homology with BLAST (http://ncbi.nim.nih.gov). The sequence data of 18S rDNA were aligned with those of the related fungal strains retrieved from the Genbank databases using CLUSTALX and analyzed to identify the fungal strain and its closest neighbors. A Jukes-Cantor corrected distance matrix was constructed by 168 DNADIST program of PHYLIP (Felsenstein 1989), which was used to assign sequences in various operational 169 taxonomic units (OTU) using DOTUR at 97\% sequence similarity cut off (Schloss and Handelsman 2005). A phylogenic tree was constructed from the evolutionary distance data by PHYLIP software (Felsenstein 1989).

\section{Inoculum}

The discs ( $7 \mathrm{~mm}$ diameter) cut from the periphery of the $72 \mathrm{~h}$-old culture of the selected strain of Aspergillus niger NS-2 growing on PDA plates, incubated at $30^{\circ} \mathrm{C}$, were used as inoculum.

\section{Enzyme Production}

To know the productivities of various hydrolytic enzymes, the selected strain of A. niger was cultivated as surface and solid state cultures on wheat bran based liquid and solid media, while the solid medium consisted of $5 \mathrm{~g}$ wheat bran moistened with $7.5 \mathrm{~mL}$ of distilled water. Three independent experiments, with 3 replicates, were carried out for each type of fermentation and the data represented as mean \pm standard deviation.

\section{Surface Culture Fermentation (SCF)}

$50 \mathrm{~mL}$ of production medium consisting of yeast extract $(0.3 \% \mathrm{w} / \mathrm{v})$, malt extract $(0.3 \% \mathrm{w} / \mathrm{v})$, peptone $(0.5 \% \mathrm{w} / \mathrm{v})$, and wheat bran, procured from a local flour mill, $(2.5$ $\% \mathrm{w} / \mathrm{v})$, dispensed in a $250 \mathrm{~mL}$ Erlenmeyer flask was autoclaved. The flasks in triplicate were inoculated with five discs $(7 \mathrm{~mm}$ dia) cut from the periphery of actively growing colonies of $A$. niger on PDA plates and incubated at $30^{\circ} \mathrm{C}$ in stationery state for 96 hours. The contents of each flask were centrifuged at $10,000 \times \mathrm{g}$ for $30 \mathrm{~min}$ at $4^{\circ} \mathrm{C}$ after decanting, these were free from the mycelium and analysed for various enzyme activities, which were expressed as IU/mL as well as IU/g dry substrates used in the medium (malt extract+yeast extract+peptone + wheat bran). This was stored at $-20^{\circ} \mathrm{C}$ till further use. 


\section{Solid state fermentation (SSF)}

Five grams of wheat bran, taken in $250 \mathrm{~mL}$ Erlenmeyer flask and moistened with $7.5 \mathrm{~mL}$ of distilled water was taken as the medium for SSF. The flasks were autoclaved and inoculated in triplicate with five discs $(7 \mathrm{~mm}$ dia) cut from the periphery of actively growing colonies of $A$. niger on PDA plates and incubated at $30^{\circ} \mathrm{C}$ in stationery state for 96 hours. The enzymes were extracted by adding $100 \mathrm{~mL}$ of distilled water to each flask and churning in a laboratory blender. The contents of each flask were then filtered through a metallic sieve, and the solid residue was pressed to release remaining liquid. The contents of each flask were centrifuged at $10,000 \times \mathrm{g}$ for $30 \mathrm{~min}$ at $4^{\circ} \mathrm{C}$ after separating the mycelium by decanting and analysed for various enzyme activities. The yields were expressed as $\mathrm{IU} / \mathrm{g}$ dry substrate. This was stored at $-20^{\circ} \mathrm{C}$ till further use.

\section{Enzyme Assays}

The supernatants obtained from surface culture and solid state cultures were used as the extracellular enzyme preparations and assayed at $50^{\circ} \mathrm{C}, \mathrm{pH} 4.0$ for cellulases (exo$\beta$-1,4-glucanase, endo- $\beta$-1,4-glucanase, and $\beta$-1,4-glucosidase), xylanase, mannanase, pectinase, $\alpha$-amylase, and glucoamylase.

\section{Cellulases}

Complete cellulase complex was measured in terms of endo- $\beta$-1,4-glucanase, exo- $\beta$-1,4-glucanase, and $\beta$-glucosidase activities (Mandels et al. 1976), and the same have been expressed in terms of CMCase, FPase, and salicinase activities using CMC, Whatmann filter paper strips, and salicin, respectively, as the substrates, and determining the $\mu$ moles glucose liberated/min using dinitrosalicylic acid reagent (Miller 1959).

\section{Hemicellulases}

Hemicellulases were determined in terms of endo- $\beta-1,4-x y l a n a s e$ and endo- $\beta$ 1,4-mannanase activities using xylan (Bailey et al. 1992) and locust bean gum (Stålbrand et al. 1993), respectively, as the substrates and determining the $\mu$ moles xylose and mannose liberated/min, respectively using dinitrosalicylic acid reagent (Miller 1959).

\section{Pectinase}

The enzyme was estimated by using pectin as the substrate (Minjares Carranco et al. 1997) and determining the $\mu$ moles of galactouronic acid liberated/min, using dinitrosalicylic acid reagent (Miller 1959).

\section{Amylases}

These were determined in terms of $\alpha$-amylase and glucoamylase activities using soluble starch as the substrate by determining the hydrolysis of starch using iodine and the amount of glucose liberated, using dinitrosalicylic acid reagent (Miller 1959), respectively. $\alpha$-amylase activity was expressed as equivalent to enzyme which reduces the colour of starch-iodine complex by $10 \%$ in $10 \mathrm{~min}$ at $50^{\circ} \mathrm{C}$ (Fuwa 1954), while glucoamylase activity was expressed in terms of $1 \mu \mathrm{M}$ of glucose liberated per min (Cori 1955). 


\section{Bioconversion of Domestic Waste Residues into Sugars with Enzyme Preparation from Aspergillus niger NS-2}

The depolymerising enzyme cocktail from A. niger NS-2 was also evaluated for its capability in the bioconversion of domestic wastes rich in cellulose, hemicellulose, starch, and pectin into reducing sugars. Various residues belonging to wheat bran, potato peels, carrot peels, orange peels, and composite waste (having $25 \%$ each of wheat bran, potato peels, carrot peels, and orange peel fractions), were dried in oven at $70^{\circ} \mathrm{C}$ to a constant weight. These were then ground, separately, to a particle size corresponding to 20 mesh using an electrical grinder. $10 \mathrm{~g}$ each of the powdered residues were then dispensed in $50 \mathrm{~mL}$ tap water, separately, in $100 \mathrm{~mL}$ Erlenmeyer flasks and subjected to pre-hydrolysis steam treatment for $1 \mathrm{~h}$ at $120^{\circ} \mathrm{C}$.

Enzymatic hydrolysis of various steam-pretreated domestic waste residues was carried out, separately, at $50^{\circ} \mathrm{C}$ on a rotary water bath shaker after adding $30 \mathrm{~mL}$ of enzyme cocktail from surface culture fermentation by $A$. niger NS-2 in each and continuously stirred at $200 \mathrm{rpm}$. All the experiments were performed at enzyme to substrate ratios of 54 CMCase, 5.4 FPase, $9 \beta$-glucosidase, 648 xylanase, 27 mannanase, $8549 \alpha$-amylase, 129 glucoamylase, 21 pectinase $\mathrm{U} / \mathrm{g}$ dry residue, and $10 \mathrm{mg} / \mathrm{mL}$ chloramphenicol for $72 \mathrm{~h}$. The samples were withdrawn from the reaction mixtures at regular intervals of $24 \mathrm{~h}$ and analyzed for total reducing sugars by DNSA reagent method of Miller (1959).

Total carbohydrates in the domestic waste residues were determined by phenolsulphuric acid method in terms of glucose (Dubois et al. 1956). All analysis were done in triplicate, and data were expressed in terms of $100 \%$ dry matter basis. The results of enzymatic hydrolysis have been depicted in terms of carbohydrate conversion and sugar yields. Carbohydrate conversion was expressed as percentage of the reducing sugar yield after enzymatic hydrolysis in comparison to the total carbohydrates in domestic waste residues, as determined in terms of glucose (Table 4). Sugar yields have been expressed in terms of mass of sugars produced/mass of dry domestic waste residue.

\section{RESULTS}

\section{Screening and Isolation of Fungi Producing Hydrolytic Depolymerising Enzymes}

After extensive screening of fungal biodiversity from various natural habitats of Chandigarh City, a total of 98 strains were isolated, on the basis of their ability to hydrolyze any of the polysaccharides. Of these, 10 fungi showing clear zone ratio of more than 1.25 on CMC and xylan, were short listed (Table 1). These were differentiated on the basis of microscopic and macroscopic examination of the colonies and belonged mainly to Aspergillus, Fusarium, Penicillium, and Rhizopus. Out of these, the isolate NS2 showed the clearing on all the carbohydrates with the highest clear zone ratio on the plates and was thus selected for further studies. Colonies of this strain on potato dextrose agar at $30^{\circ} \mathrm{C}$ were initially white, quickly becoming black with conidial production. Reverse of the colony was pale yellow, and growth produced radial fissures in the agar. The strain grew rapidly on the CYA medium at $30^{\circ} \mathrm{C}$ reaching a size of 45 to $60 \mathrm{~mm}$ in 5 
days. The middle of the colony was yellow brownish to pitchy. The conidial head was globular at an early stage; it broke into several cylindrical textures, and the top vesicle was globular. The conidiophores grew larger when the fungus grew and turned brown in colour at the late stage of growth.

Table 1. Hydrolytic Capabilities of Fungal Isolates Towards Various Polysaccharides Supplemented in Potato-Based Agar Plates

\begin{tabular}{llccccc} 
Isolates & Colony colour & \multicolumn{5}{c}{ Clear zone ratios on various polysacharides* } \\
& & CMC & Xylan & Locust bean & Starch & Pectin \\
NS-1 & Brown & 2.05 & 2.15 & gum & - & 1.53 \\
NS-2 & Black & 2.55 & 2.90 & 2.00 & 2.95 & 2.05 \\
NS-3 & Grey & 1.95 & 1.55 & - & - & - \\
NS-4 & Dark brown & 1.45 & 1.99 & - & 1.57 & - \\
NS-5 & Green & 1.48 & 2.00 & 1.45 & - & - \\
NS-6 & Yellowish brown & 1.45 & 1.57 & 1.48 & 2.55 & 1.40 \\
NS-7 & Pink & 1.43 & - & - & 2.62 & - \\
NS-8 & Grey & - & 1.54 & 1.36 & 2.62 & 1.45 \\
NS-9 & Black & 2.10 & 2.60 & - & - & - \\
NS-10 & White & 1.25 & 1.45 & 1.40 & - & 1.40 \\
& & & & & &
\end{tabular}

The microscopic analysis of the conial head of the strain showed its resemblance with Aspergillus (Fig. 1). The $18 \mathrm{~S}$ rDNA of NS-2 was successfully amplified by PCR with size of about 897 bp (Fig. 2).
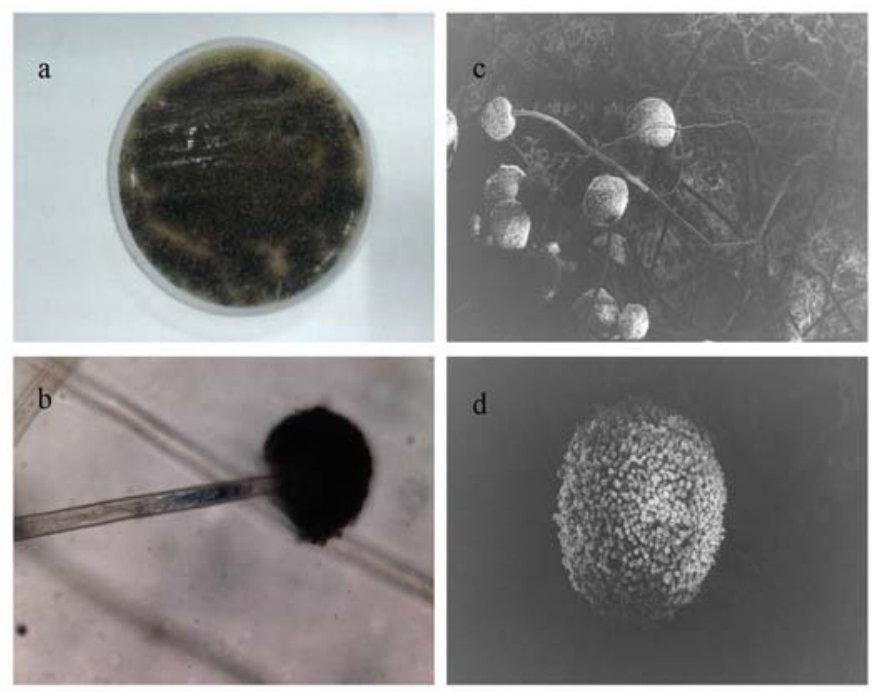

Fig. 1. Morphology of the cellulose-hemicellulaseamylase-pectinase producing fungus NS-2. (a) Colony growing on PDA medium at $30^{\circ} \mathrm{C}$ for 4 days; (b,c) conidiophores viewed under a light microscope at the magnitude of 1000 and scanning electron microscope at a magnitude of 2000; (d) conidia viewed under a scanning electron microscope at the magnitude of 2000

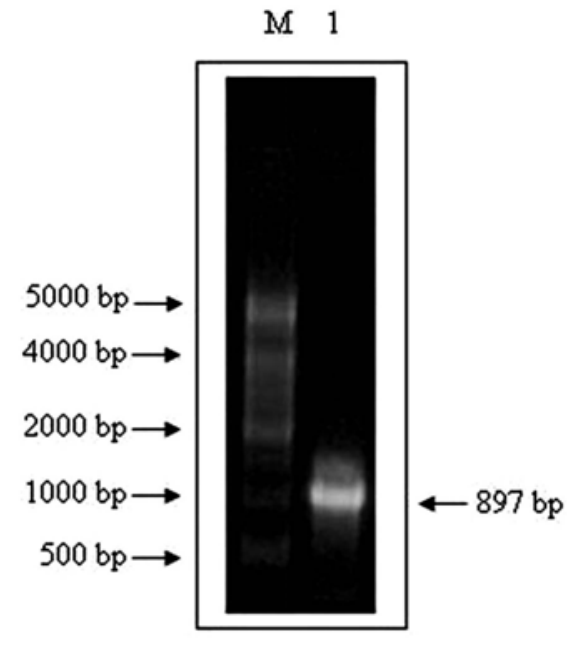

Fig. 2. Agarose gel electrophoresis for PCR products of the 18S rDNA amplified from strain NS-2. Lane M: DNA molecular weight marker (Chromous Cat. No. LAD02); 1: sample NS-2 
The aligned sequence of this amplified 897 bp 18S rDNA segment from NS-2 (Fig. 3) was submitted to GenBank, and after homology searching against the GenBank or the proprietary fungal DNA databases, the sequence of NS-2 was found to share $99 \%$ similarity with those of Aspergillus niger (NCBI Acc No. AM270052) as depicted in alignment view and distance matrix (Table 2). A phylogenetic relationship was established through the alignment and cladistic analysis of homologous nucleotide sequences among these fungal species (Fig. 4), and NS-2 appeared to be closest to the genus Aspergillus and was classified as a species variant of Aspergillus niger.

\begin{abstract}
ACGGGAGCAGACCACCGGGATTGCCTCAGTAACGGCGAGTGAAGCGGCAAGAGCTCAAAT TTGAAAGCTGGCTCCTTCGGAGTCCGCATTGTAATTTGCAGAGGATGCTTTGGGTGCGGC CCCCGTCTAAGTGCCCTGGAACGGGCCGTCAGAGAGGGTGAGAATCCCGTCTTGGGCGGG GTGTCCGTGCCCGTGTAAAGCTCCTTCGACGAGTCGAGTTGTTTGGGAATGCAGCTCTAA ATGGGTGGTAAATTTCATCTAAAGCTAAATACTGGCCGGAGACCGATAGCGCACAAGTAG AGTGATCGAAAGATGAAAAGCACTTTGAAAAGAGAGTTAAACAGCACGTGAAATTGTTGA AAGGGAAGCGCTTGCGACCAGACTCGCCCGCGGGGTTCAGCCGGCATTCGTGCCGGTGTA CTTCCCCGTGGGCGGGCCAGCGTCGGTTTGGGCGGCCGGTCAAAGGCCCCTGGAATGTAG TGCCCTCCGGGGCACCTTATAGCCAGGGGTGCAATGCGGCCAGCCTGGACCGAGGAACGC GCTTCGGCACGGACGCTGGCATAATGGTCGTAAACGACCCGTCTTGAAACACGGACCAAG GAGTCTAACATCTACGCGAGTGTTCGGGTGTCAAACCCGTGCGCGCAGTGAAAGCGAACG GAGGTGGGAGCCCCCTTGCGGGGCGCACCATCGACCGATCCTGATGTCTTCGGATGGATT TGAGTAAGAGCGTAGCTGTGGGGACCCGAAAGATGGTGAACTATGCCTGAATAGGGCGAA GCCAGAGGAAACTCTGGTGGAGGCTCGCAGCGGTTCTGACGTGCAAATCGATCGTCAAAT TTGGGTATAGGGGCGAAAGACTAATCGAACCATCTAGTAGCTGGTCCTGCCGAGTCT
\end{abstract}

Fig. 3. Aligned sequence data ( $897 \mathrm{bp}$ ) of $18 \mathrm{~S}$ rDNA amplified from strain NS-2

Table 2. Nucleotide Alignment View and Distance Matrix Table with NS-2 Sequence Taken as Reference Sequence

NCBI Accession No.
emb|AM270052.1|
emb|AM270051.1|
dbj|AP007172.1|
gb|EU840206.1|
gb|FJ358285.1|
gb|EU840227.1|
emb|FM179606.1|
gb|AY176751.1|
gb|EF413621.1|
gb|EF411064.1|

$\begin{array}{lr}\text { Organism Name } & \text { Score } \\ & \\ \text { Aspergillus niger } & 99 \\ \text { Aspergillus niger } & 99 \\ \text { Aspergillus oryzae } & 97 \\ \text { Emericella nidulans } & 96 \\ \text { Leiothecium ellipsoideum } & 96 \\ \text { Emericella nidulans } & 96 \\ \text { Aspergillus fumigatus } & 96 \\ \text { Eurotium herbariorum } & 96 \\ \text { Eupenicillium javanicum } & 95 \\ \text { Eupenicillium limosum } & 95\end{array}$




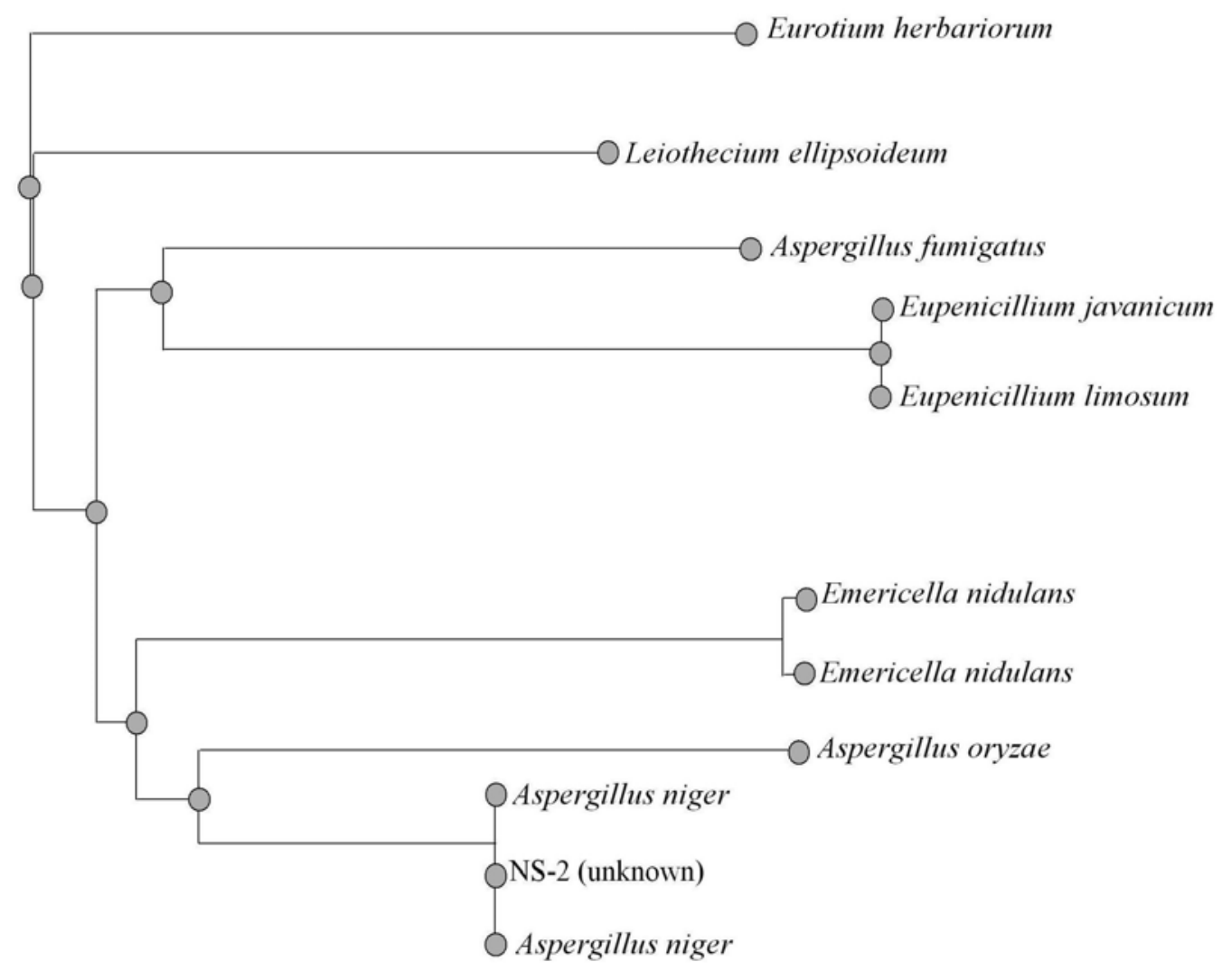

Fig. 4. Phylogenetic trees showing relationship of strain NS-2 with other related fungal species retrieved from GenBank based on their sequence homologies of 18S rDNA

\section{Enzyme Production by Aspergillus niger NS-2}

The strain of A. niger NS-2 was found to be capable of growing luxuriantly as a surface culture as well as a solid-state culture on wheat bran based media and produced significant levels of various depolymerising enzyme components, required for hydrolysis of various lignocellulosic waste residues, rich in cellulose, hemicellulose, starch, and pectin, after $96 \mathrm{~h}$ (Table 3). The successful growth was probably due to the presence of adequate amounts of various nutrients such as proteins, amino acids, fats, carbohydrates including cellulose, hemicellulose, starch, pectin, ash, calcium, and magnesium in wheat bran. All of these nutrients were necessary for the production of enzymes as well as cell mass formation (Roussos et al. 1991). The enzyme cocktail included the complete cellulase complex with very high endo-glucanase $(18 \mathrm{CMC} \mathrm{U} / \mathrm{mL} ; 333 \mathrm{CMC} \mathrm{U} / \mathrm{g})$, and $\beta$-glucosidase $(3 \mathrm{U} / \mathrm{mL} ; 30 \mathrm{U} / \mathrm{g})$, xylanase $(216 \mathrm{U} / \mathrm{mL} ; 1679 \mathrm{U} / \mathrm{g})$, mannanase $(\mathrm{U} / \mathrm{mL}$; $160 \mathrm{U} / \mathrm{g}), \alpha$-amylase $(3183 \mathrm{U} / \mathrm{mL} ; 19698 \mathrm{U} / \mathrm{g})$, glucoamylase $(43 \mathrm{U} / \mathrm{mL} ; 474 \mathrm{U} / \mathrm{g})$, and pectinase $(7 \mathrm{U} / \mathrm{mL} ; 110 \mathrm{U} / \mathrm{g})$ activities respectively in surface culture and solid state fermentations of wheat bran after $96 \mathrm{~h}$. A comparison of the two fermentations revealed 1.5 to 4.5 fold increase in yields per $\mathrm{g}$ of dry matter in SCF compared to SSF for different activities (Table 3). All the enzymes were quite stable at $-20^{\circ} \mathrm{C}$, as there was no decline in their activities after three freeze-thaw cycles. 
Table 3. Yields of Various Hydrolytic Depolymerising Enzymes Achieved after 96 h Fermentation by Surface and Solid State Cultures of $A$. niger NS-2 in Wheat Bran Based Media

\begin{tabular}{|c|c|c|c|}
\hline \multirow{3}{*}{$\begin{array}{l}\text { Enzymatic } \\
\text { activities }\end{array}$} & \multicolumn{3}{|c|}{ Enzyme yields* } \\
\hline & \multicolumn{2}{|c|}{ SCF } & SSF \\
\hline & IU/mL & $\begin{array}{l}\text { IU/g dry } \\
\text { substrates }\end{array}$ & IU/g dry substrate \\
\hline CMCase & $18 \pm 1$ & $500 \pm 28$ & $333 \pm 19$ \\
\hline FPase & $1.8 \pm 0.17$ & $50 \pm 4.9$ & $15 \pm 0.7$ \\
\hline$\beta$-glucosidase & $3 \pm 0.1$ & $83 \pm 2.8$ & $30 \pm 1$ \\
\hline Xylanase & $216 \pm 5$ & $6000 \pm 139$ & $1679 \pm 85$ \\
\hline Mannanase & $9 \pm 0.4$ & $250 \pm 11$ & $160 \pm 6$ \\
\hline$\alpha$-amylase & $3183 \pm 75$ & $88416 \pm 2083$ & $19698 \pm 800$ \\
\hline Glucoamylase & $43 \pm 2$ & $1194 \pm 56$ & $474 \pm 21$ \\
\hline Pectinase & $7 \pm 0.4$ & $194 \pm 11$ & $110 \pm 6$ \\
\hline
\end{tabular}

*Data represents the mean \pm standard deviation of three independent experiments with three replicates each

\section{Bioconversion of Domestic Waste Residues into Sugars with Enzyme Preparation from Aspergillus niger NS-2}

The enzyme preparation from A. niger NS-2 worked very well in the bioconversions of various carbohydrates present in various steam-pretreated domestic solid wastes including wheat bran (WB), potato peels (PP), carrot peels (CP), orange peels $(\mathrm{OP})$, and composite waste $(\mathrm{CW})$ residues by producing significant amounts of reducing sugars (Fig. 5). Maximum bioconversion was observed during the first $24 \mathrm{~h}$ of incubation and further incubation brought about slight gradual rise. Highest conversions were noted after $72 \mathrm{~h}$ reaction at $50^{\circ} \mathrm{C}$ in all the residues revealing the maximum conversion efficiencies of $92,91,92,89$ and $89 \%$ in $\mathrm{WB}, \mathrm{PP}, \mathrm{CP}, \mathrm{OP}$ and $\mathrm{CW}$, respectively (Table 5), while the maximum sugar yields observed in these were 0.66 , $0.51,0.48,0.48$ and $0.52 \mathrm{~g} / \mathrm{g}$ of respective dry residues (Fig. 5).

Table 4. Total Carbohydrate Contents of Various Domestic Waste Residues Used in the Study

$\begin{array}{lc}\text { Residue } & \begin{array}{c}\text { Carbohydrate } \\ (\%)\end{array} \\ \text { Wheat bran } & 72.0 \\ \text { Potato Peel } & 56.2 \\ \text { Carrot Peel } & 52.0 \\ \text { Orange peel } & 54.0 \\ \text { Composite waste } & 58.7\end{array}$


Table 5. Pattern of Carbohydrate Conversions in Various Domestic Waste Residues

$\begin{array}{lccccc}\begin{array}{l}\text { Time } \\ \text { (h) }\end{array} & \text { Wheat bran } & \text { Potato peels } & \text { Carrot peels } & \text { Orange peels } & \begin{array}{c}\text { Composite } \\ \text { waste }\end{array} \\ 0 & 16.6 \pm 0.6 & 12.5 \pm 0.6 & 23.1 \pm 1.2 & 35.2 \pm 2.1 & 17.0 \pm 1.0 \\ 24 & 70.8 \pm 4.2 & 72.9 \pm 5.5 & 65.3 \pm 3.8 & 66.7 \pm 3.4 & 66.4 \pm 3.8 \\ 48 & 87.5 \pm 6.0 & 88.9 \pm 4.1 & 78.8 \pm 3.5 & 77.8 \pm 3.5 & 78.3 \pm 4.6 \\ 72 & 91.6 \pm 7.2 & 90.7 \pm 5.0 & 92.3 \pm 5.1 & 88.9 \pm 5.5 & 88.5 \pm 4.0\end{array}$

*Data represent the mean \pm standard deviation of three independent experiments with three replicates each

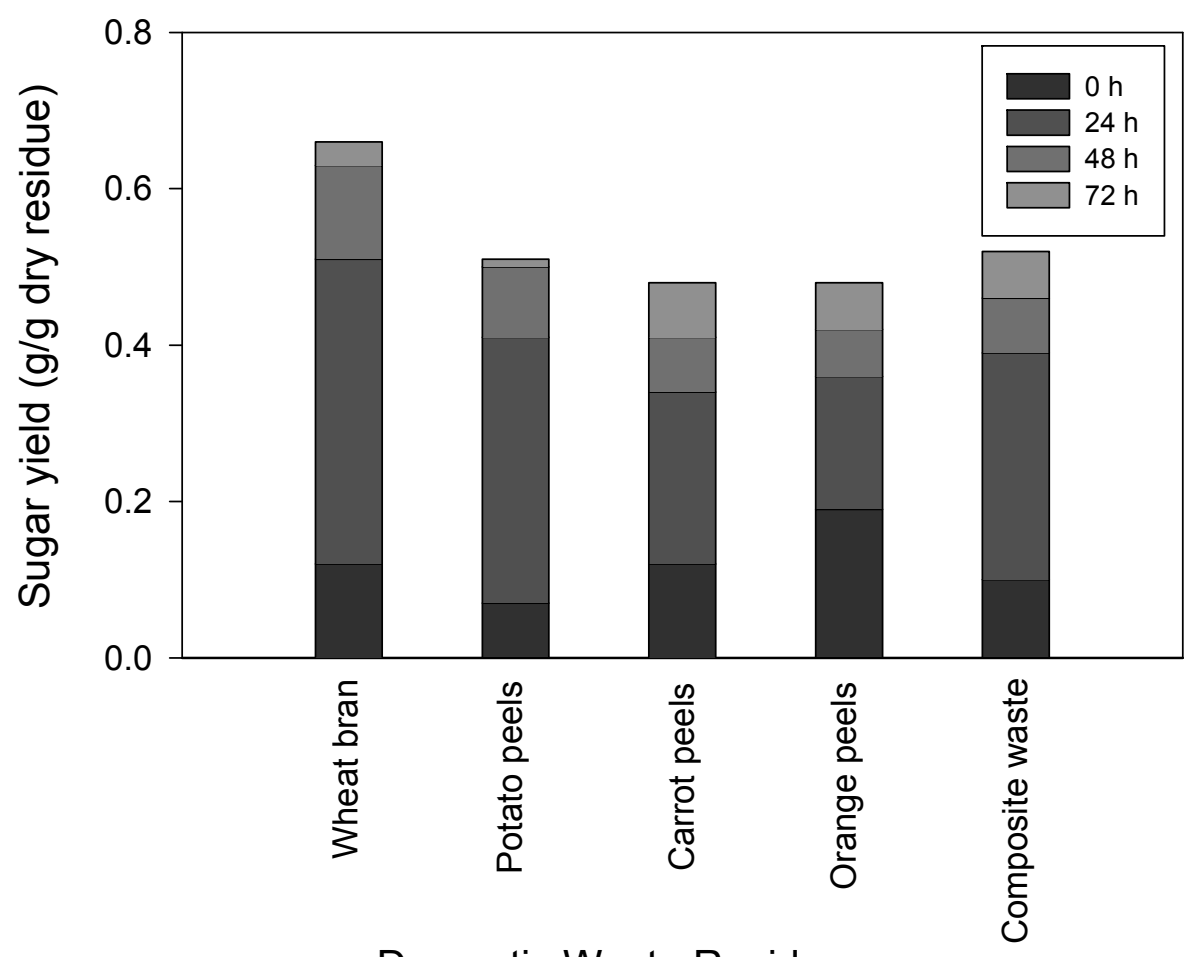

Fig. 5. Pattern of reducing sugar yields from various domestic waste residues during $72 \mathrm{~h}$ of enzymatic bioconversions

\section{DISCUSSION}

As fungi can utilize a broader range of polysaccharides in comparison to bacteria, therefore, interest in the search of fungal species capable of producing a mixture of biomass depolymerising enzymes including cellulases, hemicellulases, amylases, and 
pectinases is increasing, so that an enzyme cocktail can be obtained for the complete hydrolysis of different polysaccharides of plant origin for the production of secondgeneration biofuels. The present study was carried out with a view of selecting fungal strains, from natural habitats, capable of producing a wide range of depolymersing enzymes.

Fungi are the main microbial sources of cellulase, hemicellulase, and amylase, although a few bacteria have also been reported to yield these enzyme components. Fungal enzymes have been the major subjects of investigation over the years, as these catalyze the decay of lignocellulosic material in our ecosystem, and some fungi produce extracellular cellulases in significant amounts. Although several fungi have been evaluated for their ability to degrade cellulosic substrates, the fungal species belonging to genera Trichoderma and Aspergillus have been studied in detail for their cellulase production potential (Kumar et al. 2008). Besides Trichoderma viride, the other mesophilic strains producing cellulases are Fusarium oxysporium, Piptoporus betulinus, Penicillium echinulatum, P. purpurogenum, Aspergillus niger, A. fumigatus, and Chaetomium erraticum (Kumar et al. 2008; Martins et al. 2008; Soni and Soni 2010). The cellulases from Aspergillus usually have high $\beta$-glucosidase activity but lower endoglucanase levels, whereas Trichoderma has high endoglucanase and exoglucanase but lower $\beta$-glucosidase levels, and hence has limited efficiency in cellulose hydrolysis. Thermophillic fungi such as Mucor pusillus, Thermoascus aurantiacus, Sporotrichum thermophile, Humicola lanuginosa, Allescheria terrestris, Malbranchea pulchella, and Rhizomucor miechei, also produce the cellulase complex and can degrade native cellulose (Grajek 1987; Kaur and Satyanarayana 2004). Such thermophilic organisms may be valuable sources of thermostable cellulases. Chaetomium species are well known among the cellulolytic fungi for their potential to degrade cellulosic waste and for single cell protein (SCP) production (Fanhrich and Irrgang 1982; Sandhu and Puri 1989; Ganju et al. 1990; Lakshmikant and Mathur 1990; Soni et al. 1999; Soni and Soni 2010).

Many earlier studies have reported the production of cellulases, hemicellulases, pectinases, and amylases from fungi in submerged as well as solid state fermentations, individually or in a mixture of few enzymes by employing expensive substrates including pure carbohydrates, nitrogen sources, and a lot of minerals. The production of such a cocktail of various depolymerising enzymes by a single organism and that too in higher titres, as observed in the present study, on a simple wheat bran based medium is a novelty and this preparation thus can be a potential candidate for employment in the simultaneous saccharification of cellulose, xylan, mannan, starchy substances, and pectin for the production of second-generation alcohol.

The co-production of various depolymerising enzymes in the present study is probably due to the presence of various inducer carbohydrates including starch $(34 \%)$, xylan $(18.3 \%)$, glucan $(10.5 \%)$, arabinan $(10.1)$, galactan $(1.1 \%)$ in addition to crude protein $(13.5 \%)$, and lignin $(5 \% \mathrm{w} / \mathrm{w})$ in the wheat bran (Palmarola-Adrados et al. 2005), used as the substrate the two fermentations. Further, 1.5 to 4.5 fold increase in the yields per $g$ of dry matter in SCF compared to SSF for different activities is perhaps due to the requirement of higher water activity by the organism or the presence of some useful nutrients present in yeast extract, malt extract, and peptone supplemented in the medium for SCF considering the low concentration $(2.5 \%)$ of wheat bran in comparison to $(40 \%)$ 
the medium for SSF. A cocktail of xylanases, mannanases, and pectinases has been earlier reported by Puchart et al. (1999) from a thermophilic fungus, Thermomyces lanuginosus with yields of 291, 21.6, and $0.1 \mathrm{U} / \mathrm{mL}$ in submerged state fermentation $(\mathrm{SmF})$, while the production of endoglucanse $(0.19 \mathrm{U} / \mathrm{mL})$, endoxylanase $(0.17 \mathrm{U} / \mathrm{mL})$, $\alpha$-arabinosidase $(0.06 \mathrm{U} / \mathrm{mL})$, and polygalactourinase $(0.10 \mathrm{U} / \mathrm{mL})$ from Trichoderma reesei Rut C-30 has been reported on different lignocellulosic materials (Olsson et al. (2003). Co-production of xylanolytic, pectinolytic, and cellulolytic enzymes has also been reported by Kaur and Satyanarayana (2008) in Sporotricum thermophile in SSF with yields of 334, 3.0, and $7.7 \mathrm{U} / \mathrm{g}$ dry mouldy bran under unoptimized conditions. A mixture of cellulases and xylanases produced by $P$. echinulatum in $\mathrm{SmF}$ revealed the maximum levels of 1.53, 0.27, 0.31, and $3.29 \mathrm{U} / \mathrm{mL}$ for CMCase, FPase, $\beta$-glucosidase and xylanase, respectively (Martins et al. 2008). Ikram-ul-Haq et al. (2006) produced CMCase $(2.79 \mathrm{U} / \mathrm{mL})$, FPase $(1.75 \mathrm{U} / \mathrm{mL}), \beta$-glucosidase $(4.66 / \mathrm{mL})$, and xylanase $(189.7 \mathrm{U} / \mathrm{mL})$ on wheat bran by co-cultures of $A$. niger and T. viride in $\mathrm{SmF}$. Few reports have also appeared on the cellulolytic capabilities of A. niger strains, but their yields were less than those observed in the present study. Sridevi et al. (2009) studied the production of Cellulases by A. niger on natural and pretreated lignocellulosic wastes in $\mathrm{SmF}$ and indicated that the pretreated saw dust had yielded the highest CMCase $(7.2 \mathrm{U} / \mathrm{mL})$ and FPase $(6.3 \mathrm{U} / \mathrm{mL})$ while rice bran produced $\beta$-glucosidase $1.04 \mathrm{U} / \mathrm{mL}$. The kinetics of cellulase production from an indigenous strain of A. niger MS82 carried out by Sohail et al. (2009), on different carbon containing natural substrates indicated that the organism was capable of producing moderate to high levels of both endoglucanase $(1.75 / \mathrm{mL})$ and $\beta$-glucosidase (1.2U/mL).

The production of ethanol from any lignocellulosic biomass generally involves four steps - feedstock pretreatment, enzymatic saccharification, fermentation, and ethanol recovery. Few lignocellulosic residues including sugarcane bagasse, wheat straw, corn stover, spruce, and municipal solid waste have been worked upon by several workers for enzymatic bioconversion, with commercial or in-house produced cellulases, into fermentable sugars employing various pretreatment protocols including acid, alkali and steam (Kovacs et al. 2009). After pretreatment, plant cell wall polysaccharides become more susceptible to enzymatic hydrolysis that results into monomeric sugars for fermentation into ethanol (Lynd et al. 1999). Domestic solid waste residues, used in the present study on dry weight basis contained 52 to $72 \%$ carbohydrates (Table 4 ) consisting of various polysaccharides. The enzyme cocktail obtained from A. niger NS-2, as produced in the present study, worked quite well in targeting the various polysaccharide fractions in the steam pre-treated domestic waste residues of WB, PP, CP, OP and CW residue, as evident from the total reducing sugar content liberated in the reaction mixtures of individual residues. These sugars belonged mainly to glucose, mannose, galactose, xylose, and arabinose, as detected by paper chromatography (data not shown), and the same can be fermented into alcohol by employing suitable microorganisms. A few studies have reported the employment of consortia of fungal cultures or their enzyme preparations for saccharification of lignocellulosics for second generation ethanol production. In a study for ethanol production via in situ fungal saccaharification, commercial cellulases have been used with fungal saccharacification and fermentation of mild alkali and steam pretreated corn fiber (Srestha et al. 2010). In another study six 
different fungal cultures including A. niger, A. awamori, T. reesei, T. viride, Phenerochaete chrysosporium, and Pleurotus sajorcaju were used in different combinations for release of sugars for ethanol production (Patel et al. 2007). In another report the pretreated cellulosic residues were hydrolyzed by a crude enzyme preparation from $P$. chrysogenum BCC4504 containing cellulase activity combined with $A$. flavus BCC7179 preparation containing complementary $\beta$-glucosidase activity (Buaban et al. 2010).

\section{CONCLUSIONS}

A mixture of cellulolytic, hemicellulolytic, amylolytic, and pectinolytic enzymes could be produced by Aspergillus niger NS-2 in solid state fermentation (SSF) and surface culture fermentation (SCF) using wheat bran as the substrate. To best of our knowledge there has been no report about the production of such a cocktail of enzymes, and that too in higher titres from a single organism. The enzyme cocktail could efficiently hydrolyze various domestic waste residues rich in cellulose, hemicellulose, starch, and pectin and thus finds a significant application in the conversion of agricultural and domestic waste residues to produce simpler sugars that can be fermented for the production of second generation biofuels. The yields of enzyme components can be further increased after optimization of various cultural and environmental variables for efficient biomass bioconversions.

\section{ACKNOWLEDGMENTS}

This work was funded by University Grants Commission, New Delhi, under the special assistance programme (SAP) and by Department of Science \& Technology, Government of India under PURSE grant.

\section{REFERENCES CITED}

Apun, K., Jong, B. C., and Salleh, M. A. (2000). "Screening and isolation of a cellulolytic and amylolytic Bacillus from sago pith waste," Journal of General and Applied Microbiology 46, 263-267.

Bahadure, R. B., Agnihotri, U. S., and Akarte, S. R. (2010). “Assay of population density of amylase producing bacteria from different soil samples contaminated with flowing effluents," International Journal of Parasitology Research 2, 9-13.

Bahkali, A. H. (1996). "Influence of various carbohydrates on xylanase production by $V$. tricorpus," Bioresources Technology 33, 265-268.

Bailey, M. J., Biley, P., and Poutanen, K. (1992). "Inter laboratory testing of methods for assay of xylanase activity," Journal of Biotechnology 23, 257-270. 
Bakri,Y., Jacques, P., and Thonart. (2003). "Xylanase production by Penicillium canescens 10-10c in solid state fermentation," Applied Biochemistry and Biotechnology 108, 737-748.

Bhat, M. K. (2000). "Cellulases and related enzymes in biotechnology," Biotechnology Advances 189, 355-383.

Bisaria, V. S., and Ghose, T. K. (1981). "Biodegradation of cellulosic materials: Substrates, microorganisms, enzymes and products," Enzyme and Microbial Technology 3, 90-104.

Buaban, B., Inoue, H., Yano, S., Tanapongpipat, S., Ruanglek, V., Champreda, V., Pichyangkura, R., Rengpipat, S., and Eurwilaichitr, L. (2010). "Bioethanol production from ball milled bagasse using an on-site produced fungal enzyme cocktail and xylose-fermenting Pichia stipitis," Journal of Biosciences and Bioengineering 110, 18-25.

Cori, G. T. (1955). "Amylo-1,6-glucosidase," Methods in Enzymology 1, 211- 214.

da Silva, R., Lago, E. S., Merheb, C. W., Macchione, M. M., Park, Y. K., and Gomes, E. (2005). "Production of xylanase and CMCase on solid state fermentation in different residues by Thermoascus aurantiacus miehe," Brazilian Journal of Microbiology 36, 235-241.

Dhillon, S. S., Gill, R. K., Gill, S. S., and Singh, M. (2004). "Studies on the utilization of citrus peel for pectinase production using fungus Aspergillus niger," International. Journal of Environmental Studies 61, 199-210.

Dubois, M., Gibes, K. A., Hamilton, J. K., Rebers, P. A. and Smith, F. (1956). "Colorimetric method for determination of sugars and related substances," Analytical Chemistry 28, 350-353.

Fahnrich, P., and Irrgang, K. (1982). "Some characteristics of the cellulolyticum enzyme system of Chaetomium cellulolyticum," Biotechnology Letters 4, 519-524.

Felsenstein, J. (1989). "PHYLIP-Phylogeny inference package (version 3.2)" Cladistics 5, 164-166.

Fuwa, H. (1954). "A new method for micro determination of amylase activity by the use of amylose as substrate," Journal of Biochemistry 41, 583-603.

Ganju, R. K., Vithayathil, P. J., and Murthy, S. K. (1990). "Factors influencing production of cellulases by Chaetomium thermophile var. coprophile," Indian Journal of Experimental Biology 28 , 254-264.

Ikram-ul-Haq, Javed, M. M., and Khan, T. S. (2006). "An innovative approach for hyper production of cellulolytic and hemicellulolytic enzymes by consortium of A. niger and T. viride MSK- 10," African Journal of Biotechnology 5, 609-614.

Immanuel, G. R., Dhanusa., Prema, P., and Palavesam, A. (2006). "Effect of different growth parameters on endo-glucanase enzyme activity by bacteria isolated from coir retting effluents of estuarine environment," International Journal of Environmental Science and Technology 3, 25-34.

Jarvis, M. (2003). “Cellulose stacks up,” Nature 426, 611-612.

Kathiresan, K., and Manivannan, S. (2006). " $\alpha$-amylase production by Penicillium fellutanum isolated from mangrove rhizospheric soil," African Journal of Biotechnology 5, 829-832. 
Kaur, G., and Satyanarayana, T. (2004). "Production of extracellular pectinolytic, cellulolytic, xylanolytic enzyme by thermophilic mould Sporotrichum thermophile Apinis in solid state fermentation," Indian Journal of Biotechnology 3, 552-557.

Klich, M. A. (2002). Identification of Common Aspergillus Species, Ponsen \& Looijen, The Netherlands.

Kovacs, K., Macrelli, S., Szakacs, G., and Zacchi, G. (2009). "Enzymatic hydrolysis of steam-pretreated lignocellulosic materials with Trichoderma atroviride enzymes produced in-house," Biotechnology for Biofuels 2, 14-24.

Kumar, R., Singh S., and Singh, O. V. (2008) "Bioconversion of lignocellulosic biomass: Biochemical and molecular perspectives," Journal of Industrial Microbiology and Biotechnology 35, 377-391.

Lakshmikant, K., and Mathur, S. N. (1990). "Cellulolytic activities of Chaetomium globosum on different substrates," World Journal of Microbiology and Biotechnology 6, 23-26.

Lynd, L. R., Wyman, C. E., and Gerngross, T. U. (1999) "Biocommodity engineering," Biotechnology Progress 15, 777-793.

Mandels, M., Andreotti, R. E., and Roche, C. (1976). "Measurements of saccharifying cellulases," Biotechnology and Biophysics Symposium 6, 21-23.

Mangelli, P., and Forchias, F. (1999). "Regulation of the cellulase complex production by Saccobolus saccaboloides induction and repression by carbohydrates," Mycologia 91 359-364.

Martins, L. F., Kolling, D., Camassola, M., Dillon, A. J., and Ramos, L. P. (2008). "Comparison of Penicillium echinulatum and Trichoderma reesei cellulases in relation to their activity against various cellulosic substrates," Bioresource Technology 99, 1417-1424.

Miller, G. L. (1959). "Use of DNSA reagent for determination of reducing sugars," Analytical Chemistry 32, 426-428.

Minjares-Carranco, A., Trejo-Aguilar, B. A., Guillermo A., and Viniegra-Gonzalez, G. (1997). "Physiological comparision between pectinase producing mutants of Aspergillus niger adopted either to solid state fermentation or submerged fermentation," Enzyme and Microbial Technology 21, 25-31.

Mishra, S., and Behera, N. (2008). "Amylase activity of a starch degrading bacteria isolated from soil receiving kitchen wastes," African Journal of Biotechnology 7 , 3326-3331.

Naidu, G. S. N., and Panda, T. (1998). "Production of pectinolytic enzymes - A review," Bioprocess Engineering 19, 355-361.

Olsson, L., Christensen, T. M. I. E., Hansen, K. P. and Palmqvist, E. A. (2003). "Influence of the carbon source on production of cellulases, hemicellulases and pectinases by Trichoderma reesei Rut C-30," Enzyme and Microbial Technology 33, 612-619.

Palmarola-Adrados, B., Chotěborská, P., Galbe, M. and Zacchi, G. (2005). "Ethanol production from non-starch carbohydrates of wheat bran," Bioresource Technology 96, 843-850. 
Pandey, A., Soccol, C. R., Nigam, P., and Soccol, V. T. (2000). "Biotechnological potential of agro-industrial residues and sugarcane Bagasse," Bioresource Technology 74, 69-80.

Patel, S. J., Onkarappa, R., and Shobha, K. S. (2007). "Comparative study of ethanol production from microbial pretreated agricultural residues," Journal of Applied Sciences and Environmental Management 11, 137-141.

Phothichittol, K., Nitisinprasert, S., and Keawsompong, S. (2006). "Isolation, screening and identification of mannanase producing microorganisms," Kasetsart Journal of Natural Science 40, 26-38.

Puchart, V., Katapodis, P., Biely, P. L., Kremnický., Christakopoulos, P., Vranská, M., Kekos, D., Macris, B. J., and Bhat, M. K. (1999). "Production of xylanases, mannanases, and pectinases by the thermophilic fungus Thermomyces lanuginosus," Enzyme and Microbial Technology 24, 355-361.

Qi, Z.T., and Kong, H. Z. (1997). Flora Fungorum Sinicorum - Aspergillus et Teleomorphi Cognati. Beijing: Science Press

Raper, K. B., and Fennell, D. I. (1965). The Genus Aspergillus, Williams \& Wilkins, Baltimore, MD, USA.

Reda, A. B., Hesham, M. Y., Mahmoud, A. S., and Ebtsam, Z. A. (2008). "Production of bacterial pectinase(s) from agro-industrial wastes under solid state fermentation conditions," Journal of Applied Sciences Research 41, 1708-1721.

Roussos, S., Raimbault, M., Viniegra-Gonzalez, G., Saucedo-Casteneda, G., and Lonsane, B. K. (1991). "Scale up of cellulase production by Trichoderma harzianum on a mixture of sugar cane baggase and wheat bran in solid state fermentation system," Micología Neotropical Aplicada 4, 83-98.

Sandhu, D. K., and Puri, R. (1989). "Expression of $\beta$-glucosidase and endo- $\beta$-1,4glucanase during development of Chaetomium fusisporale and their characterization," Journal of Basic Microbiology 29, 1519-1526.

Schloss, P. D., and Handelsman, J. (2005). "Introducing DOTUR, a computer grogram for defining operational taxonomic units and estimating species richness," Applied Environmental Microbiology 71, 1501-1506

Shin, C. S., Lee, J. P., Lee, P. S., and Park, S. C. (2000). "Enzyme production of Trichoderma reesi Rut C-30 on a various lignocellulosic substrates," Applied Biochemistry and Biotechnology 84-86, 237-245.

Shrestha, P., Khanal, S. K., Pometto, A. L., and van Leeuwen, J. (2010). "Ethanol production via in situ fungal saccharification and fermentation of mild alkali and steam pretreated corn fiber," Bioresources Technology 101, 8698-8705.

Sohail, M., Siddiqi, R., Ahmad, A., and Khan, S. A. (2009). "Cellulase production from Aspergillus niger MS82: effect of temperature and pH," New Biotechnology 25, 437441.

Soni, R., Sandhu, D. K., and Soni, S. K. (1999). "Localization and optimization of cellulase production in Chaetomium erraticum," Journal of Biotechnology 73, 43-51.

Soni, S. K., and Soni, R. (2010). "Regulation of cellulase synthesis," BioResources 5, 8198. 


\section{bioresources.com}

Sridevi, A., Narasimha, G., and Reddy, B. R. (2009). "Production of cellulase by Aspergillus niger on natural and pretreated lignocellulosic wastes," The Internet Journal of Microbiology 7, 1.

Stålbrand, H., Siika-aho, M., and Viikari, L. (1993). "Purification and characterization of two $\beta$-mannanases from Trichoderma reesei," Journal of Biotechnology 29, 229-242.

Teathe, R. M., and Wood, P. J. (1982). "Use of Congo red polysaccharide interaction in enumeration of cellulolytic bacteria from bovine rumen," Applied. Environmental and Microbiology 43, 777-780.

Tomme, P., Warren, R. A., and Gilkes, N. R. (1995). "Cellulose hydrolysis by bacteria and fungi," Advanced Microbial Physiology 37, 1-81.

Zhang, Y. H. P., and Lynd, L. R. (2004). "Toward an aggregated understanding of enzymatic hydrolysis of cellulose: Non complexed cellulose systems," Biotechnology and Bioengineering 88, 797-824.

Zhao, K., Zhou, D. P., Ping, W. X. and Ge, J. P. (2004). "Study on preparation and regeneration of protoplast from taxolproducing fungus Nodulisporum sylviforme," Nature Science 2, 52-59.

Article submitted: October 14, 2010; Peer review completed: November 20, 2010;

Revised version received and accepted: December 27, 2010; Published: December 29, 2010. 